\title{
PENERAPAN PEMBELAJARAN INKUIRI TERBIMBING UNTUK MENINGKATKAN KEAKTIFAN DAN HASIL BELAJAR IPA PADA SISWA KELAS VIII-B SMPN 4 MADIUN
}

\author{
Dwi Muchindasari \\ SMP Negeri 4 Madiun \\ E-mail:dwimuchin@yahoo.com
}

\begin{abstract}
Abstrak
Kondisi pembelajaran yang efektif dan berkualitas dapat tercipta bila siswa terlibat secara aktif, siswa memiliki motivasi belajar tinggi, siswa mempunyai minat dan perhatian dalam belajar. Dalam proses pembelajaran diharapkan siswa mendapat pengalaman untuk membangun konsep sehingga belajar tidak berorientasi pada guru tetapi lebih terpusat pada siswa. Oleh karena itu peningkatan kualitas pendidikan harus ditopang oleh tumbuhnya daya inovasi guru. Hasil studi pendahuluan dengan melakukan observasi selama mengajar siswa kelas VIII-B di SMP Negeri 4 Madiun ditemukan beberapa permasalahan. Tanggung jawab guru berusaha untuk mengaktifkan siswa dalam pembelajaran sehingga siswa memperoleh konsep bukan dari menghafal atau hanya transfer ilmu melainkan melalui proses. Permasalahan di atas dapat diatasi dengan memberikan model pembelajaran yang variatif yang menjadikan siswa sebagai pusat kegiatan belajar yang salah satunya melalui model pembelajaran Inkuiri Terbimbing.
\end{abstract}

Kata kunci : Inkuiri Terbimbing, Keaktifan, Hasil Belajar

\section{PENDAHULUAN}

Ilmu Pengetahuan Alam (IPA) berkaitan dengan cara mencari tahu (inkuiri) tentang alam secara sistematis, sehingga IPA bukan hanya sebagai penguasaan kumpulan pengetahuan yang berupa fakta-fakta, konsep-konsep atau prinsipprinsip saja, tetapi juga merupakan suatu proses penemuan. Pendidikan IPA menekankan pada pemberian pengalaman langsung untuk mengembangkan kompetensi agar siswa menjelajahi dan memahami alam sekitar secara alamiah. Pendidikan IPA diarahkan untuk mencari tahu dan berbuat sehingga dapat membantu siswa untuk memperoleh pemahaman yang lebih mendalam tentang diri sendiri dan alam sekitar

Kondisi pembelajaran yang efektif dan berkualitas dapat tercipta bila siswa terlibat secara aktif, siswa memiliki motivasi belajar tinggi, siswa mempunyai minat dan perhatian dalam belajar. Proses pembelajaran yang aktif dan berkualitas terjadi jika siswa mempunyai hak dan kebebasan untuk bersuara, berpendapat dan berargumen di dalam kelas yang berkaitan dengan materi pelajaran di kelas. Saat berlangsungnya proses pembelajaran sebenarnya yang aktif bukan hanya gurunya dan memandang siswa seperti benda pasif, yang hanya mendengarkan dan me-matuhi apa yang disampaikan oleh guru. Guru harus dapat menciptakan kondisi yang dapat memunculkan motivasi dan minat untuk mengikuti pembelajaran, sehingga antara siswa dan guru sama-sama aktif dalam transfer ilmu pengetahuan baik dari guru ke siswa, dari siswa ke guru dan juga antar siswa.

Menurut Kiswardianta (2009) dalam proses inkuiri, siswa belajar dan dilatih untuk berpikir kritis. Inkuiri memberikan kepada siswa pengalaman-pengalaman belajar yang nyata dan aktif. Siswa diharapkan dapat menyelidiki mengapa suatu peristiwa dapat terjadi serta mengumpulkan dan mengolah data secara ilmiah untuk mencari jawabannya. Implementasi metode ini lebih menekankan pada pencarian (search) pengetahuan daripada perolehan (acquisition) pengetahuan.

Berdasarkan pengalaman dan pengamatan selama mengajar IPA di SMPN 4 Madiun banyak dijumpai permasalahan dalam pembelajaran. Permasalahan tersebut antara lain rendahnya keaktifan siswa dalam kegiatan pembelajaran terutama dalam materi sistem gerak pada manusia. Sebenarnya guru sudah berupaya untuk mengaktifkan siswa dalam kegiatan pembelajaran, misalnya mengajak siswa untuk praktikum, diskusi kelompok dan tanya jawab. Selain hal di atas banyak siswa beranggapan bahwa IPA adalah pelajaran yang banyak menghafal. Hal ini juga 


\section{JEMS (Jurnal Edukasi Matematika dan Sains)}

Tersedia online di: http://e-journal.ikippgrimadiun.ac.id/index.php/JEMS

Volume 4, Nomor 1, Maret 2016, hal 19 -25

terjadi pada saat siswa belajar materi sistem gerak pada manusia. Beberapa siswa bahkan langsung mengatakan tidak suka pelajaran IPA karena banyak hafalan dan sulit. Keadaan seperti ini dapat menjadikan siswa menjadi malas dan tidak aktif dalam proses belajar mengajar sehingga dapat menurunkan hasil belajar.

Tugas guru adalah mengetahui kesulitan siswa dalam belajar dan merupakan hak siswa untuk mendapatkan pembelajaran dengan baik. Guru berkewajiban mendeteksi lebih awal kesulitan siswa dan berusaha untuk segera mencari pemecahan. Sebagai guru yang profesional sudah sepatutnya melaksanakan penelitian agar pembelajaran lebih baik dan siswa dapat mencapai nilai di atas KKM. Perlu dipikirkan suatu inovasi pembelajaran agar siswa aktif dalam pembelajaran dan dapat belajar sambil bermain sehingga siswa merasa senang dan tidak terpaksa untuk belajar.

Inovasi pembelajaran dilakukan agar pembelajaran lebih kreatif dan berdampak pada perbaikan hasil belajar untuk tujuan yang sifatnya kognisi, ketrampilan dan budi pekerti. Oleh karena itu peningkatan kualitas pendidikan harus ditopang oleh munculnya daya inovasi guru. Inovasi model pembelajaran adalah salah satu cara untuk memperbaiki kualitas proses pembelajaran. Dengan

perbaikan proses maka diharapkan akan memperbaiki mutu pendidikan.

\section{METODE PENELITIAN}

Penelitian ini dilakukan untuk mendeskripsikan keterlaksanaan pembelajaran Inkuiri Terbimbing untuk meningkatkan keaktifan dan hasil belajar IPA. Deskripsi keterlaksanaan pembelajaran diperoleh dari masalah-masalah yang dihadapi di kelas untuk dicari pemecahannya dengan dukungan data empiris dari lapangan. Penelitian juga dimaksudkan untuk mengungkapkan permasalahan secara menyeluruh dan kontekstual dengan memanfaatkan peneliti sebagai instrumen kunci. Berdasarkan keadaan di atas maka pendekatan penelitian ini adalah penelitian tindakan kelas (action research).

Penelitian ini dilaksanakan di kelas VIII-B SMPN 4 Madiun semester ganjil tahun pelajaran 2015/2016. Subyek penelitian adalah siswa-siswi kelas VIII-B SMPN 4 Madiun tahun pelajaran 2015/2016 yang berjumlah 29 terdiri dari 15 lakilaki dan 14 perempuan. Kegiatan pembelajaran dilakukan dalam bentuk kelompok. Tiap kelompok terdiri dari 4 siswa dan dipilih secara heterogen.

Analisis kualitatif dilakukan secara deskriptif pada data keterlaksanaan pembelajaran, Aktivitas siswa dan hasil belajar siswa. Penelitian ini menggunakan teknik analisis deskriptif kualitatif. Analisis kualitatif dilakukan secara deskriptif, yaitu metode penelitian yang bersifat menggambarkan kenyataan atau fakta sesuai dengan data yang diperoleh dengan tujuan untuk mengetahui keterlaksanaan pembelajaran, keaktifan siswa serta hasil belajar yang dicapai siswa dari aspek kognitif selama proses pembelajaran. Uraian analisis data pada masingmasing data adalah sebagai berikut.

\section{Keterlaksanaan Pembelajaran Inkuiri Terbimbing}

Lembar observasi memuat butir-butir yang harus tampak pada Pembelajar-an Inkuiri Terbimbing dan masing-masing butir diskor. Hasil observasi keterlaksanaan pembelajaran dipersentase dengan rumus:

$$
P=\frac{(10 \% \times X)+(80 \% \times Y)+(10 \% \times Z)}{Q}
$$

Keterangan :

$\mathrm{P}=$ persentase keterlaksanaan pembelajaran

$\mathrm{X}=$ jumlah skor kegiatan pendahuluan

$\mathrm{Y}=$ jumlah skor kegiatan inti

$\mathrm{Z}=$ jumlah skor kegiatan penutup

$\mathrm{Q}=$ jumlah skor maksimum kegiatan pembelajaran

\section{Keaktifan Siswa}

Lembar observasi berisi butir-butir aktivitas siswa yang harus tampak dalam pembelajaran Inkuiri Terbimbing dengan dan masing-masing butir diskor. Data yang berupa skor kemudian diolah sehingga diperoleh presentase dengan menggunakan rumus.

$\% a$

$$
s_{i}=\frac{s_{i} \quad a \quad v}{s_{i}} \quad m \quad \times 100
$$

\section{Data Hasil Belajar Kognitif}

Data hasil belajar kognitif siswa berdasarkan skor ulangan harian yang diberikan setelah masing-masing siklus. Ketuntasan belajar siswa dilihat berdasarkan:

1) Ketuntasan perorangan (individu), siswa dianggap telah "tuntas belajar" apabila daya serap mencapai $75 \%$. 


\section{JEMS (Jurnal Edukasi Matematika dan Sains)}

Tersedia online di: http://e-journal.ikippgrimadiun.ac.id/index.php/JEMS

Volume 4, Nomor 1, Maret 2016, hal 19 - 25

2) Ketuntasan kelompok (klasikal), dianggap telah "tuntas belajar" apabila mencapai $80 \%$ dari jumlah siswa yang mencapai daya serap minimal $75 \%$,

$$
K=\frac{A}{B} x 100 \%
$$

Keterangan :

$\mathrm{K}=$ persentase keberhasilan

$\mathrm{A}=$ jumlah siswa yang memperoleh skor di atas $75 \%$

$\mathrm{B}=$ jumlah seluruh siswa

\section{HASIL DAN PEMBAHASAN}

\section{Paparan Data dan Temuan Siklus I}

Pada siklus I kegiatan yang dilakukan meliputi empat tahap yaitu tahap perencanaan tindakan, pelaksanaan tindakan, observasi tindakan, dan refleksi tindakan di mana masingmasing kegiatan dijelaskan sebagai berikut.

\section{Perencanaan Tindakan Siklus I}

Kegiatan perencanaan tindakan siklus I dilakukan berdasarkan hasil studi pendahuluan, antara lain observasi proses pembelajaran sebelumnya, wawancara teman guru pengajar IPA dan siswa. Rencana tindakan ini berbentuk langkah-langkah perencanaan yaitu mempersiapkan tindakan dan observasi untuk memperoleh data. Perencanaan tindakan pada siklus I adalah pembelajaran Inkuiri Terbimbing untuk peningkatkan keaktifan dan hasil belajar siswa. Beberapa hal yang dilakukan pada perencanaan tindakan siklus I antara lain mempersiapkan: Rencana Pelaksanaan Pembelajaran, Lembar Kerja, Kisi-kisi soal, Naskah soal, kunci jawaban soal dan skor nilai, Lembar daftar, Lembar observasi keterlaksanaan pembelajaran, lembar observasi aktivitas siswa selama proses pembelajaran, lembar catatan, sumber belajar yang berupa buku-buku yang relevan, Internet dan media pembelajaran berupa alat-alat praktikum, ICT.

\section{Pelaksanaan Tindakan Siklus I}

Pelaksanaan tindakan siklus I dilakukan berdasarkan rencana tindakan yang telah disusun. Pembelajaran yang dilaksanakan adalah pembelajaran Inkuiri Terbimbing. Tahapan pembelajaran meliputi: (1) Guru menggali kemampuan awal siswa dan memotivasi siswa dengan pertanyaan, (3) guru menjelaskan tujuan pembelajaran dan membagikan LKS (4) guru membimbing siswa merumuskan masalah melalui pertanyaan-pertanyaan (5) guru membimbing siswa untuk merumuskan hipotesis, (6) guru membimbing siswa untuk merancang praktikum, (8) guru membimbing siswa melakukan praktikum untuk membuktikan hipotesis, (9) siswa mengumpulkan dan menganalisis data, (9) siswa membuat kesimpulan hasil praktikum.

\section{Observasi Tindakan Siklus I}

Observasi dilakukan untuk memperoleh informasi yang lebih mendalam tentang data aktivitas guru dan siswa serta suasana pembelajaran mulai dari awal sampai akhir tindakan. Hasil observasi dicatat dalam lembar observasi, dalam hal ini peneliti dalam hal ini dibantu oleh 2 orang observer. Seluruh observer adalah guru SMP Negeri 4 Madiun.

\section{Refleksi Tindakan Siklus I}

Berdasarkan data tentang proses pembelajaran pada lembar observasi dan dari rubrik penilaian yang telah dicapai siswa dalam pembelajaran Inkuiri Terbimbing, dapat diketahui bahwa perlu perbaikan dalam hal penerapan pembelajaran yakni: (1) pada waktu pertemuan pertama guru kelihatan kurang percaya diri dan terlihat kaku, (2) guru kurang dapat memotivasi siswa dalam pembelajaran, (3) bimbingan guru kurang merata pada semua kelompok, (4) guru kurang bisa mengatur waktu sesuai alokasi waktu yang tersedia, (5) dalam menarik kesimpulan, guru terlalu dominan.

Hal-hal yang harus dipertahankan dan ditingkatkan yakni: (1) antusias siswa terhadap pembelajaran, (2) keaktifan siswa, (3) hasil belajar siswa yaitu ranah kognitif. Peneliti dan observer berdiskusi untuk memberi masukan perlunya dilaksanakan siklus lanjutan untuk memperbaiki pelaksanaan pembelajaran yakni siklus II, mengingat (1) keterlaksanaan pembelajaran telah ada peningkatan tetapi masih kurang maksimal, (2) keaktifan siswa telah ada peningkatan tetapi masih kurang, (3) KKM secara klasikal belum terpenuhi.

Hal-hal yang perlu diperbaiki dalam siklus II adalah (1) guru harus bisa memberikan penjelasan tentang pembelajaran Inkuiri Terbimbing karena siswa terlihat masih bingung terutama pada tahap merumuskan masalah dan pengajuan hipotesis, serta menganalisa dan menyimpulkan hasil 


\section{JEMS (Jurnal Edukasi Matematika dan Sains)}

Tersedia online di: http://e-journal.ikippgrimadiun.ac.id/index.php/JEMS

Volume 4, Nomor 1, Maret 2016, hal 19 -25

praktikum, sehingga waktu yang tersedia tidak mencukupi untuk menyelesaikan seluruh kegiatan dalam skenario pembelajaran. (2) memotivasi siswa untuk aktif mencari referensi yang relevan, baik berupa buku-buku ataupun dari internet agar dalam diskusi kelompok siswa tidak hanya memberikan pertanyaan kepada siswa yang dianggap lebih tahu tetapi bisa merata kemampuannya, (3) Guru lebih banyak aktif berkeliling ke setiap kelompok untuk mengecek hasil diskusi dan kegiatan yang dilakukan masingmasing kelompok, memberi reward kelompok yang paling kompak menyelesaikan tugas yang diberikan. (4) guru harus memberikan penguatan atau memberikan motivasi siswa untuk mengemukakan pendapatnya sehingga siswa lebih aktif dalam diskusi, (5) Guru memberi tugas kepada siswa untuk membaca materi berikutnya. Dengan demikian siswa lebih dahulu membaca materi sehingga lebih siap menerima pelajaran.

\section{Paparan Data dan Temuan Siklus II}

\section{Perencanaan Tindakan II}

Kegiatan perencanaan tindakan siklus II hampir sama dengan perencanaan tindakan siklus I yaitu mempersiapkan: Rencana Pelaksanaan Pembelajaran, Lembar Kerja, Kisi-kisi soal, Naskah soal, kunci jawaban soal dan skor nilai, Lembar daftar, Lembar observasi keterlaksanaan pembelajaran, lembar observasi aktivitas siswa selama proses pembelajaran, lembar catatan, sumber belajar yang berupa buku-buku yang relevan, Internet dan media pembelajaran berupa alat-alat praktikum, ICT.

\section{Pelaksanaan Tindakan Siklus II}

Pelaksanaan Tindakan Siklus II dilakukan sebanyak dua kali pertemuan masing-masing $2 \times 40$ menit, yaitu Kamis 10 September 2015, Sabtu 19 September 2015.

\section{Observasi Tindakan Siklus II}

Pada pelaksanaan tindakan II, observasi dilakukan selama proses pembelajaran berlangsung. Guru dibantu dua orang observer yang merupakan guru IPA yaitu Saifur Rohman, S.Pd dan Dra. Siti Cholifah. Selama pelaksanaan pada siklus II ini telah terjadi peningkatan yaitu sebagian besar siswa sudah aktif dalam kegiatan praktikum, diskusi kelompok, terjadi peningkatan siswa yang bertanya atau menjawab pertanyaan dari guru, berani untuk mempresentasikan hasil praktikum. Hal ini menunjukkan bahwa siswa lebih aktif dalam mengikuti pelajaran.

\section{Refleksi Tindakan Siklus II}

Berdasarkan data tentang proses pembelajaran dan hasil belajar yang dicapai siswa, dapat diketahui bahwa aktivitas dan hasil belajar siswa mengalami peningkatan. Hal itu dapat diketahui melalui peningkatan skor yang diperoleh pada siklus I yang dibandingkan dengan siklus II. Selain itu sudah tampak keaktifan siswa dalam proses pembelajaran telah menunjukkan peningkatan. Antusias siswa dalam menjawab pertanyaan dari guru sudah lebih tinggi dari pada siklus I. Keberhasilan dalam proses pembelajaran tercapai karena mulai tampak dalam pembelajaran seperti saling ketergantungan, saling tatap muka, dan keterampilan menjalin kerjasama antar pribadi atau kemampuan antar personal dalam bekerja kelompok.

\section{Perbandingan Peningkatan Siklus I dan Siklus II}

\section{Keterlaksanaan Pembelajaran}

Hasil pengamatan keterlaksanaan pembelajaran siklus I dan siklus II ditunjukkan seperti pada Tabel 1. Berdasarkan tersebut tampak bahwa penerapan pembelajaran Inkuiri Terbimbing, dapat meningkatan keterlaksanaan pembelajaran dari siklus I ke siklus II

Tabel 1. Peningkatan Hasil Pengamatan Keterlaksanaan Pembelajaran

\begin{tabular}{lcc}
\hline Aspek yang diamati & Siklus I & Siklus II \\
\hline Pelaksanaan & 75,06 & 90,75 \\
Pengelolaan Waktu & 68,75 & 87,50 \\
Antusias Guru & 87,50 & 93,75 \\
Antusias Siswa & 75,00 & 93,75 \\
\hline
\end{tabular}


JEMS (Jurnal Edukasi Matematika dan Sains)

Tersedia online di: http://e-journal.ikippgrimadiun.ac.id/index.php/JEMS

Volume 4, Nomor 1, Maret 2016, hal $19-25$

Tabel 2. Peningkatan Keaktifan Siswa

\begin{tabular}{cccc}
\hline Tindakan & Nilai Rata-rata & Peningkatan & Persentase \\
\hline & & & \\
Siklus 1 & 68,10 & - & - \\
Siklus 2 & 86,03 & 17,93 & 17,93 \\
\hline
\end{tabular}

\section{Keaktifan Siswa}

Peningkatan keaktifan belajar siswa juga tampak dari siklus I ke siklus II. Peningkatan keaktifan belajar siswa terlihat pada Tabel 2 . Berdasarkan Tabel 2 tersebut, rata-rata klasikal meningkat dari siklus I ke siklus II sebesar $17,93 \%$.

\section{Peningkatan Hasil Belajar Kognitif}

Peningkatan hasil belajar siswa sebelum dan sesudah diterapkan pembelajaran Inkuiri Terbimbing dapat dilihat pada Tabel 3

Tabel 3. Peningkatan Hasil Belajar Siswa (Ranah Kognitif)

\begin{tabular}{lccc}
\multicolumn{1}{c}{ Tindakan } & Rata-rata & Peningkatan & Presentase \\
\hline Sebelum Tindakan & 68,73 & 0 & 0 \\
Siklus I & 76,00 & 7,27 & 6,27 \\
Siklus I & 85,00 & 9,00 & 9,00 \\
\hline
\end{tabular}

Berdasarkan Tabel 3 tersebut tampak adanya peningkatan hasil belajar ranah kognitif yaitu nilai kemampuan awal hasil belajar siswa (ranah kognitif) 68,73 kemudian setelah diterapkan pembelajaran Inkuiri Terbimbing, siklus I meningkat menjadi 76,00 dan siklus II meningkat menjadi 85,00. Hal ini menunjukkan keberhasilan perlakuan terhadap siswa.

\section{Pembahasan}

\section{Keterlaksanaan Pembelajaran Inkuiri Terbimbing}

Penerapan pembelajaran Inkuiri Terbimbing pada kelas VIII-B di SMP Negeri 4 Madiun terdiri dua siklus yaitu dua kali pertemuan pada siklus I dan dua kali pertemuan pada siklus II. Pada siklus I, guru masih memerlukan alokasi waktu yang lama untuk membimbing dan mengarahkan siswa dalam membuat rumusan masalah, menentukan hipotesis, membuat rancangan praktikum, melakukan praktikum dengan cepat dan benar, mengambil data untuk dianalisis serta membuat kesimpulan. Hal ini terjadi karena siswa belum terbiasa dengan model pembelajaran yang diterapkan oleh guru sehingga pelaksanaan dan pengelolaan waktu yang sudah direncanakan pada RPP masih kurang optimal dalam pelaksanaannya di lapangan.

Hal lain yang mengganggu keterlaksanaan pembelajaran pada siklus I adalah pada saat wakil dari kelompok mempresentasikan hasil praktikum, beberapa siswa sibuk menyelesaikan LKSnya tanpa memperhatikan teman yang presentasi. Pada siklus II, guru melakukan perbaikan yaitu selalu mengingatkan alokasi waktu kepada siswa dan memberi tugas pada siswa untuk membaca materi berikutnya dirumah sehingga siswa lebih siap dalam menerima materi. Siswa menjadi lebih siap menerima pelajaran karena mereka sudah membaca materi melalui buku ataupun melalui internet dan kendala waktu dapat teratasi.

Pada siklus II, siswa sudah mulai mengenal dan terbiasa dengan pembelajaran Inkuiri Terbimbing sehingga pembelajaran dapat berjalan lancar sesuai dengan tujuan pembelajaran. Siswa sudah mengerti bagaimana membuat rumusan masalah, menentukan hipotesis, membuat rancangan praktikum, melakukan praktikum dengan cepat dan benar, mengambil data untuk dianalisis serta membuat kesimpulan.

Berdasarkan data yang diperoleh dapat diketahui bahwa Penerapan Pembelajaran Inkuiri Terbimbing dapat meningkatkan keterlaksanaan pembelajaran yaitu meningkatnya pelaksanaan dari $75,06 \%$ pada siklus 1 menjadi $90,75 \%$ pada siklus II, pengelolaan waktu dari $68,75 \%$ pada siklus 1 menjadi 87,50 pada siklus II, antusias guru dari $87,50 \%$ pada siklus 1 menjadi $93,75 \%$ pada siklus 1 dan antusias siswa dari $75,00 \%$ pada siklus 1 menjadi $93,75 \%$ pada siklus II

\section{Peningkatan Keaktifan Siswa}

Pembelajaran aktif merupakan pembelajaran yang banyak melibatkan aktivitas siswa dalam mengakses berbagai informasi dan pengetahuan untuk dibahas dan dikaji dalam proses pembelajaran di dalam kelas. Dalam pembelajaran 


\section{JEMS (Jurnal Edukasi Matematika dan Sains)}

Tersedia online di: http://e-journal.ikippgrimadiun.ac.id/index.php/JEMS

Volume 4, Nomor 1, Maret 2016, hal 19 - 25

aktif guru lebih banyak memposisikan dirinya sebagai fasilitator yang bertugas memberikan kemudahan belajar kepada siswa. Siswa terlibat aktif dan berperan dalam proses pembelajaran, sedangkan guru banyak memberikan arahan, bimbingan dan mengatur sirkulasi jalannya proses pembelajaran.

Penerapan pembelajaran Inkuiri Terbimbing dapat meningkatkan keaktifan karena pada pembelajaran ini siswa dengan bimbingan guru dituntut untuk merumuskan masalah, membuat hipotesis, merancang praktikum, melakukan praktikum berdasarkan hasil rancangannya dan merumuskan kesimpulan hasil praktikum. Siswa belajar dengan cara mencari dan menemukan sendiri jawaban dari suatu masalah yang dipertanyakan sehingga memudahkan siswa memahami konsep. Pembelajaran Inkuiri Terbimbing dapat membantu dalam melaksanakan kegiatan pembelajaran sehingga siswa terlibat secara aktif dan menemukan makna dari materi yang mereka pelajari.

Berdasarkan data yang diperoleh diketahui bahwa pembelajaran Inkuiri Terbimbing dapat meningkatkan keaktifan siswa yaitu $68,10 \%$ pada siklus I menjadi $86,03 \%$ pada siklus II. Dalam pembelajaran ini siswa dituntut untuk menemukan sendiri konsep yang dipelajari dengan melakukan praktikum dan berinkuiri. Siswa terlibat secara aktif dan menemukan makna dari materi yang mereka pelajari.

\section{Peningkatan Hasil Belajar Kognitif}

Penerapan pembelajaran inkuiri dapat meningkatkan hasil belajar kognitif siswa karena dengan inkuiri dapat mendorong siswa untuk mencari dan menemu-kan konsep dengan lebih baik. Sanjaya (2011) yang menyatakan bahwa salah satu keunggulan inkuiri adalah menekankan pada pengembangan aspek kognitif, afektif dan psikomotorik secara seimbang sehingga pelajaran menjadi lebih bermakna. Sasono (2014) menyatakan bahwa kegiatan pembelajaran dengan pendekatan konstruktivistik, mengajar bukanlah kegiatan memindahkan pengetahuan dari dosen ke mahasiswa, melainkan suatu kegiatan yang memungkinkan membangun sendiri pengetahuannya. Menurut Suraya (2010) dalam mengajarkan konsep-konsep IPA ada bagianbagian yang menjadi tantangan tersendiri bagi seorang guru, karena proses belajarnya perlu memperhatikan keberadaan siswa yang selalu berinteraksi dengan lingkungan. Hasil interaksi ini akan berpengaruh pada pembentukan konsepkonsep yang berkaitan dengan materi IPA yang akan diajarkan. Proses belajar yang baik seharusnya dapat menumbuhkan belajar pada diri siswa agar tingkah laku mereka berubah. Proses yang terjadi bukan hanya pemberian informasi dari guru ke siswa, melainkan melalui komunikasi timbal balik antara guru dan siswa.

Berdasarkan hasil penelitian menunjukkan bahwa niai rata-rata klasikal hasil belajar ranah kognitif mengalami peningkatan yaitu 76,00 siklus I menjadi menjadi 85,00 pada siklus II. Dari paparan data pada siklus I dan II menunjukkan bahwa pembelajaran Inkuiri Terbimbing dapat meningkatkan hasil belajar siswa. Hal ini disebabkan siswa dapat lebih mudah mengingat dan memahami materi yang disajikan lewat pembelajaran Inkuiri Terbimbing. Pengalaman siswa selama praktikum membuat kesan yang mendalam dan permanen..

Terjadinya peningkatan hasil belajar kognitif ini disebabkan oleh adanya pembelajaran yang memberi kesempatan untuk belajar menemukan dan merumuskan masalah, mengajukan hipotesis berdasar pengetahuan yang dimiliki, merencanakan kegiatan praktikum, melakukan praktikum, mengumpulkan data, menganalisis data dan membuat kesimpulan.

\section{KESIMPULAN DAN SARAN}

Keterlaksanaan pembelajaran Inkuiri Terbimbing pada siswa kelas VIII-B SMPN 4 Madiun tahun pelajaran 2015/2016 dalam mempelajari IPA mengalami peningkatan yakni dari $75,06 \%$ pada siklus I menjadi $90,75 \%$ pada siklus II. Pembelajaran Inkuiri Terbimbing dapat meningkatkan keaktifan siswa. Hal ini dapat dilihat dari pencapaian pada siklus I sebesar $68,10 \%$ dan pada siklus II sebesar 86,03\%. Pembelajaran Inkuiri Terbimbing dapat meningkatkan hasil belajar siswa ranah kognitif. Hal ini dapat dilihat dari nilai rata-rata yang meningkat dari 76 pada siklus I menjadi 85 pada siklus II. Ditinjau dari pencapaian KKM maka pada siklus I mencapai 66\% dan pada siklus II mencapai 100\%.

Penerapan pembelajaran Inkuiri Terbimbing pada mata pelajaran IPA khususnya pada materi Sistem Gerak pada Manusia dapat meningkatkan keaktifan dan hasil belajar siswa, oleh karena itu disarankan kepada guru pengajar 


\section{JEMS (Jurnal Edukasi Matematika dan Sains)}

Tersedia online di: http://e-journal.ikippgrimadiun.ac.id/index.php/JEMS

Volume 4, Nomor 1, Maret 2016, hal 19 -25

IPA untuk menggunakan model pembelajaran tersebut sebagai salah satu variasi dari model pembelajaran yang diterapkan. Pembelajaran Inkuiri Terbimbing dalam penelitian ini terbukti memerlukan sarana prasarana yang mendukung yakni ketika praktikum memerlukan alat dan bahan untuk itu disarankan pada lembaga agar memberikan dukungan sehingga perkembangan lembaga khususnya dalam kualitas proses pembelajaran dapat ditingkatkan. Perlunya pengelolaan waktu secara matang oleh guru dalam menerapkan pembelajaran Inkuiri Terbimbing sehingga diperoleh hasil yang maksimal.

\section{DAFTAR PUSTAKA}

Sanjaya, Wina. (2011). Strategi Pembelajaran Berorintasi Pada Standar Proses. Jakarta: Kecana Prenada Media Group
Sasono, M., \& Pujianto, P. (2015). Pendekatan Konstruktivistik Melalui Metode Learning Cycle Untuk Meningkatkan Penguasaan Konsep Fisika Pada Matakuliah Astrofisika. JURNAL PENDIDIKAN FISIKA DAN KEILMUAN, 1(1), 35-53.

Kiswardianta, R. B. (2009). Implementasi Pendekatan Ketrampilan Proses dengan Metode Inkuiri Melalui Kolaborasi Guru dan Dosen (Team Teaching) untuk meningkatkan Hasil Belajar. Jurnal Pendidikan, 15(2).

Suraya, S. N. (2015). Pengembangan Perangkat Pembelajaran IPA Berorientasi Model Inkuiri untuk Melatihkan Ketrampilan Proses di SD. Jurnal Pendidikan, 16(1). 